\title{
ЛИТОЛОГО-ПЕТРОГРАФИЧЕСКИЕ ОСОБЕННОСТИ КОЛЛЕКТОРОВ БАЖЕНОВСКОЙ СВИТЫ НА ЮГО-ВОСТОКЕ ЗАПАДНО-СИБИРСКОЙ ПРОВИНЦИИ (ТОМСКАЯ ОБЛАСТЬ)
}

\author{
Недоливко Наталья Михайловна', \\ nedolivko@tpu.ru
}

\author{
Перевертайло Татьяна Геннадьевна', \\ ptg@tpu.ru
Национальный исследовательский Томский политехнический университет, Россия, 634050, г. Томск, пр. Ленина, 30.

\begin{abstract}
Актуальность исследования продиктована необходимостью расширения ресурсной базы Западно-Сибирского региона, в том числе и Томской области, за счет вовлечения в разработку трудноизвлекаемых запасов нефти, сосредоточенных в нефтематеринской баженовской свите (титон-берриасс).

Цель исследования: выявить особенности литологического состава и строения баженовского резервуара на прогнозно-перспективной для добычи нефти территории Томской области

Объект исследования: битуминозные отложения баженовской свиты, вскрытые бурением на локальном поднятии в Тамратской впадине (Нюрольский осадочный бассейн), Пудинский нефтегазоносный район Западно-Сибирской нефтегазоносной провинции (Томская область), из которых получен приток нефти.

Методы: геофизические исследования, макрокопическое описание керна, петрографический и рентгенофазовый анализы. Результаты. В продуктивном разрезе баженовской свиты выявлены границы распространения разуплотненных пород - коллекторов нефти и газа. Приведена их литологическая характеристика, установлены текстурно-структурные особенности и вещественный состав. Выделено семь литотипов: 1 - алеврито-силицитовые аргиллиты со следами жизнедеятельности илоядных животных и трубчатыми раковинами; 2 - битуминозные силицито-аргиллиты с кремнистыми прослойками и остатками кремниевых водорослей; 3 - битуминозные силициты глинистые радиоляриевые; 4 - битуминозные силициты радиоляриевые с трубчатыми раковинами и кремнистыми прослойками; 5 - битуминозные аргиллиты силицитовые радиоляриевые со следами биотурбации и остатками криноидей; 6 - силицит-аргиллиты радиоляриевые с остатками водорослей; 7- силицит-глинисто-карбонатные породы. Выяснено, что накопление осадков баженовской свиты осуществлялось при стабильно низкодинамичном застойном режиме седиментации в относительно глубоководных морских условиях восстановительной геохимической среды. Установлена связь минерального состава и содержания сапропелевого органического вещества с трансгрессивно-регрессивной цикличностью осадконакопления: наиболее обогащен кремнистым материалом и органическим веществом литотип 4, максимальное количество этих компонентов приходится на точку инверсии трансгрессивно-регрессивного цикла. Баженовский коллектор имеет смешанное происхождение, формировался при стадиальном литогенезе (седиментогенез-катагенез) и постстадиальных процессах. Пустотное пространство в нем представлено ультратонкими биопустотами и порами, межслоевыми и внутрислоевыми трещинами
\end{abstract}

\section{Ключевые спова:}

Нюрольский осадочный бассейн, Западная Сибирь, Томская область, титон-берриасс,

баженовская свита, битуминозные аргиллиты, нефтематеринские породы, литотип, коллектор.

\section{Введение}

Проблемы поиска, разведки и добычи углеводородов из нетрадиционных коллекторов - низкопроницаемых битуминозных сланцев - в последние годы вызывают повышенный интерес. Этот интерес обусловлен огромными разведанными запасами углеводородного сырья, сосредоточенного в недрах России, США, Канады, Китая, Аргентины, Израиля, Ирана, Индии и других стран, а также огромными затратами, связанными с его извлечением.

Термин «сланец» носит собирательный характер и в действительности объединяет породы различного литологического состава: глинистые и кремнистые породы, доломиты, известняки, мергели и др. породы, имеющие различное происхождение и характеризующиеся даже в пределах одного месторождения большой вертикальной и латеральной изменчивостью. Например, широко известные сланцы Bakken и Exshaw play (США и Канада) состоят из переслаивания плотных доломи- тов, алевролитов, песчаников, сланцев и карбонатных коллекторов [1].

По условиям седиментации битуминозные сланцы могут быть морскими [2, 3] и озерными $[3,4]$ образованиями, что определяет литологический облик ассоциации сланцевых пород и их пространственную локализацию.

Поэтому разработка технологий добычи сланцевой нефти должна учитывать, прежде всего, происхождение, состав и свойства пород, вмещающих углеводороды.

В России перспективы добычи сланцевой нефти связываются с отложениями баженовской свиты (титон-берриас), сформированными в относительно глубоководных морских условиях. Они представляют собой уникальный геологический объект, простираясь на обширной (около 1 млн км²) территории Западно-Сибирской нефтегазоносной провинции и характеризуясь высоким (около $14 \%$ ) содержанием органического вещества, находящегося в твердом (около $12 \%$ ) и жидком (до 2,7 \%) 
состояниях, соответственно в виде недозревшей керогена II типа - и легкой извлекаемой нефти $[5,6]$. Обладая низкими фильтрационно-емкостными свойствами, свита по промысловым характеристикам относится к разряду низкопроницаемых коллекторов, а запасы нефти, сосредоточенные в ней, - к трудноизвлекаемым.

В Томской области в связи с высокой выработкой нефти в традиционных юрских и меловых коллекторах, представленных алевролитами и песчаниками, вовлечение в разработку ресурсов баженовской нефти является одним из острых вопросов нефтегазодобывающей промышленности. Наличие жидких углеводородов в баженовской свите доказано на целом ряде месторождений Томской области (Снежном, Западно-Квензерском, ЮжноФестивальном). Наиболее перспективной территорией для обнаружения залежей нефти в баженовской свите является район Нюрольской впадины [7]. Согласно исследованиям И.В. Гончарова и др. $[8,9]$, Конторовича А.Э. и др. [10], породы баженовской свиты здесь обладают отличным генерационным потенциалом, среднее содержание органического углерода (Сорг) в них составляет $5 . .13 \%$. Вместе с тем промышленная нефтегазоносность отложений баженовской свиты на территории исследования не была установлена, причиной чему могут быть как особенности пород самой баженовской свиты, так и несовершенство применяемых технологий добычи сланцевой нефти. Выяснению литологических особенностей баженовского коллектора, содержащего трудноизвлекаемую нефть, и посвящена настоящая работа.

\section{Объект исследования}

Объект исследования - битуминозные отложения баженовской свиты, вскрытые бурением на одной из площадей, в тектоническом плане приуроченной к одноименному локальному поднятию на северо-востоке Тамратской впадины (юго-восток Нюрольского осадочного бассейна). В административном отношении территория располагается в Каргасокском районе Томской области, согласно принятому нефтегазогеологическому районированию, относится $\kappa$ Пудинскому нефтегазоносному району Западно-Сибирской нефтегазоносной провинции. В одной из скважин после проведения гидроразрыва пласта был получен приток нефти.

\section{Фактический материал и методы исследования}

Выполнено макроскопическое описание керна; проведен петрографический анализ 28 шлифов (Шл.), отобранных в 2 скважинах (скв.) в интервале глубин (Гл.) $3118 . .3145$ м (скв. 1) и $2788 . .2815$ м (скв. 2) с использованием поляризационного микроскопа POLAM L-213M (изготовитель АО «ЛОМО», г. Санкт-Петербург); изучен фазовый состав пород (47 образцов) на рентгеновском дифрактометре GBC MMA 011. Сочетание этих методов позволяет установить особенности строения и состава пород и провести их систематизацию.

\section{Результаты исследований}

Отложения баженовской свиты толщиной $27 \mathrm{~m}$ согласно залегают на глинистых морских породах георгиевской свиты $\left(\mathrm{J}_{3} \mathrm{~km}_{\mathrm{gr}}\right)$, имеющих толщину $3,90 \ldots 4,6$ м и перекрывающих регионально продуктивный горизонт $Ю_{1}$. Вверх по разрезу баженовская свита постепенно сменяется морскими глинистыми отложениями куломзинской свиты $\left(\mathrm{K}_{1} \mathrm{~b}_{\mathrm{kl}}\right)$ толщиной около $40 \mathrm{~m}$.

Согласно макроскопическому описанию керна, разрез сложен битуминозными аргиллитами темно-серыми с бурым оттенком и буровато-черными, однородными, тонкоплитчатыми с ровным и раковистым изломом и листоватыми с неотчетливой горизонтальной, пологоволнистой и линзовидной слоистостью за счет прослоев и послойно уплощенных линз карбонатного, фосфатного и кремнистого состава. В аргиллитах встречаются ростры и онихиты белемнитов, створки пелеципод, иногда трубчатые раковины (в диаметре до 1,5 мм). В нижней и верхней частях разреза в породах присутствуют следы жизнедеятельности типа Chondrites, принадлежащие мелким донным илоядным организмам. Повсеместно развита тонкая рассеянная и послойная сыпь, кристаллы и мелкие конкреционные стяжения пирита. В разрезе отмечается чередование плотных и дезинтегрированных пород, разбитых трещинами различной ориентировки на разноразмерные куски. Породы обладают сильным запахом, напоминающим запах керосина, поверхность их жирная на ощупь, на пальцах остается масляный след.

По результатам рентгенофазового анализа, минеральными компонентами изученных пород являются кварц $-12,1 \ldots 66,7 \%$, альбит $-9,2 . .19,2 \%$, ортоклаз - 0,7...8,3\% ; мусковит - 7,6...18,8 \%, иллит $-4,4 \ldots 13,9 \%$, хлорит $-0,9 \ldots 6,9 \%$, каолинит $-0,9 \ldots 3,7 \%$, анкерит - 0,5...4,6\% (иногда до $64,8 \%$ ), кальцит - 0,5...10\% (в единичных образцах до 17,6 и 47,6 \%), пирит - 2,1...13,8 \% . В отдельных пробах альбит, ортоклаз, хлорит, иллит, каолинит, мусковит, анкерит и кальцит отсутствуют. Содержание глинистого материала, к которому отнесены тонкодисперсные полевые шпаты, а также слюды и собственно глинистые минералы (хлорит, иллит, каолинит) в породах составляет от 18,9 до $61,9 \%$.

Аргиллиты характеризуются (рис. 1) высокими значениями электрического сопротивления на кривых бокового каротажа (LLD); слабо дифференцированной кривой самопроизвольной поляризацией (PS), имеющей, в отличие от большинства разрезов баженовской свиты, отрицательное отклонение (что, согласно макроскопическому описанию керна, отвечает трещиноватым аргиллитам). Для них характерны высокие значения нейтрон-гамма каротажа (CFTC), отражающие низкое водосодержание и очень высокие значения гаммакаротажа (GR), обусловленные высокой радиоактивностью пород за счет содержания радиоактивных изотопов в глинистых (полевых шпатах, слю- 
Скважина 1

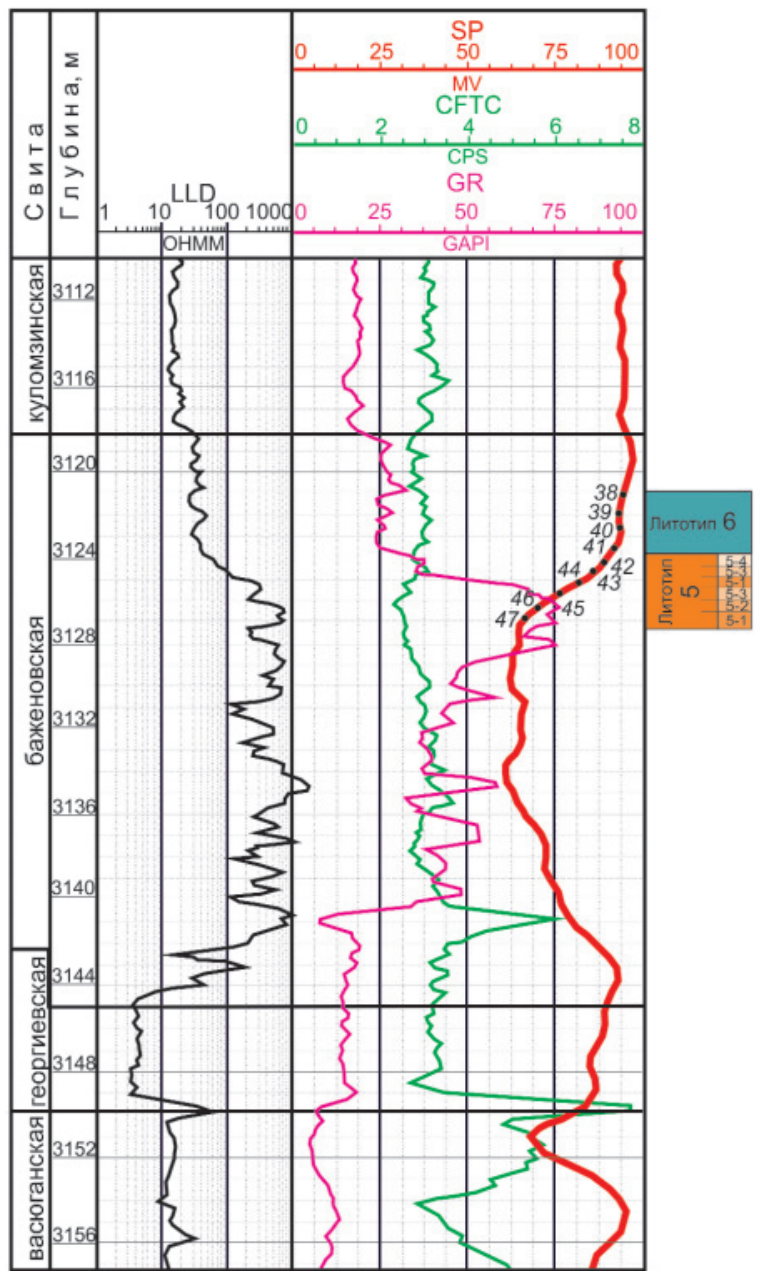

Скважина 2

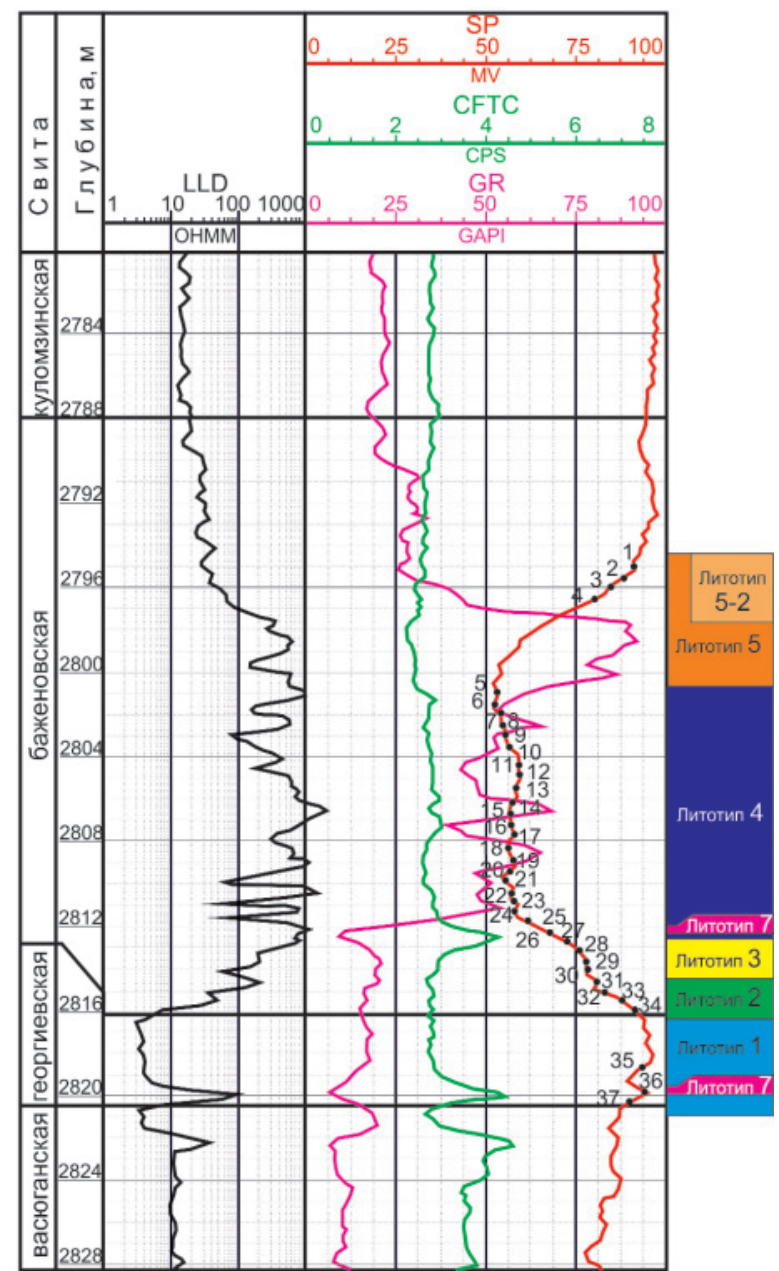

Рис. 1. Геофизическал характеристика и положение литотипов в разрезе баженовской свиты на территории исследования

Fig. 1. Geophysical characteristic and position of lithotypes in the Bazhenov Suite section in the study area

дах, иллите) и фосфатных минералах, так и за счет урана, сконцентрированного в рассеянном органическом веществе [11].

По литологическим особенностям и составу породообразующих компонентов в изученном разрезе выделено семь литотипов (рис. 1): литотип 1 характеризует отложения георгиевской свиты, литотипы 2-6 выделены в разрезе баженовской свтиты, литотип 7 встречается в разрезе георгиевской и в нижней части баженовской свиты. Снизу вверх по разрезу литотипы представлены: алеврито-силицитовыми аргиллитами со следами жизнедеятельности илоядных животных и трубчатыми раковинами (литотип 1); битуминозными силицитоаргиллитами с кремнистыми прослойками и остатками кремниевых водорослей (литотип 2); битуминозными силицитами глинистыми радиоляриевыми (литотип 3); битуминозными силицитами радиоляриевыми с трубчатыми раковинами и кремнистыми прослойками (литотип 4); битуминозными аргиллитами силицитовыми радиоляриевыми со следами биотурбации и остатками криноидей (литотип 5); силицит-аргиллитами радиоляриевы- ми с остатками водорослей (литолип 6); силицитглинисто-карбонатными породами (литотип 7).

Литотип 1 (рис. 2, А) - алеврито-силицитовые аргиллиты со следали биотурбации и трубчатыли раковинали - темно-серые, черные с бурым оттенком, однородные и скрыто слоистые, с округлыми послойно уплощенными конкрециями и сыпью пирита, следами жизнедеятельности мелких илоядных животных, остатками трубчатых (диаметром менее 1 мм) и створчатых раковин (кальцитизированных и пиритизированных), фосфатизированных онихитов и кальцитовых пиритизированных ростров (диаметром менее 0,5 см) белемнитов, редких кремнистых раковин радиолярий, сильно растворенных и пиритизированных.

Структура пород пелитовая, мелкоалевритовая (обломочный материал размером до 0,01...0,02 мм составляет $15 \%$ породы), лепидобластовая за счет ориентированного чешуйчатого глинисто-гидрослюдистого агрегата. Глинистый материал представляет тонкодисперсную смесь каолинита, иллита, мусковита, хлорита и полевых шпатов, составляет $58 . . .61,8$ \% и преобладает над аллотигенным и ау- 

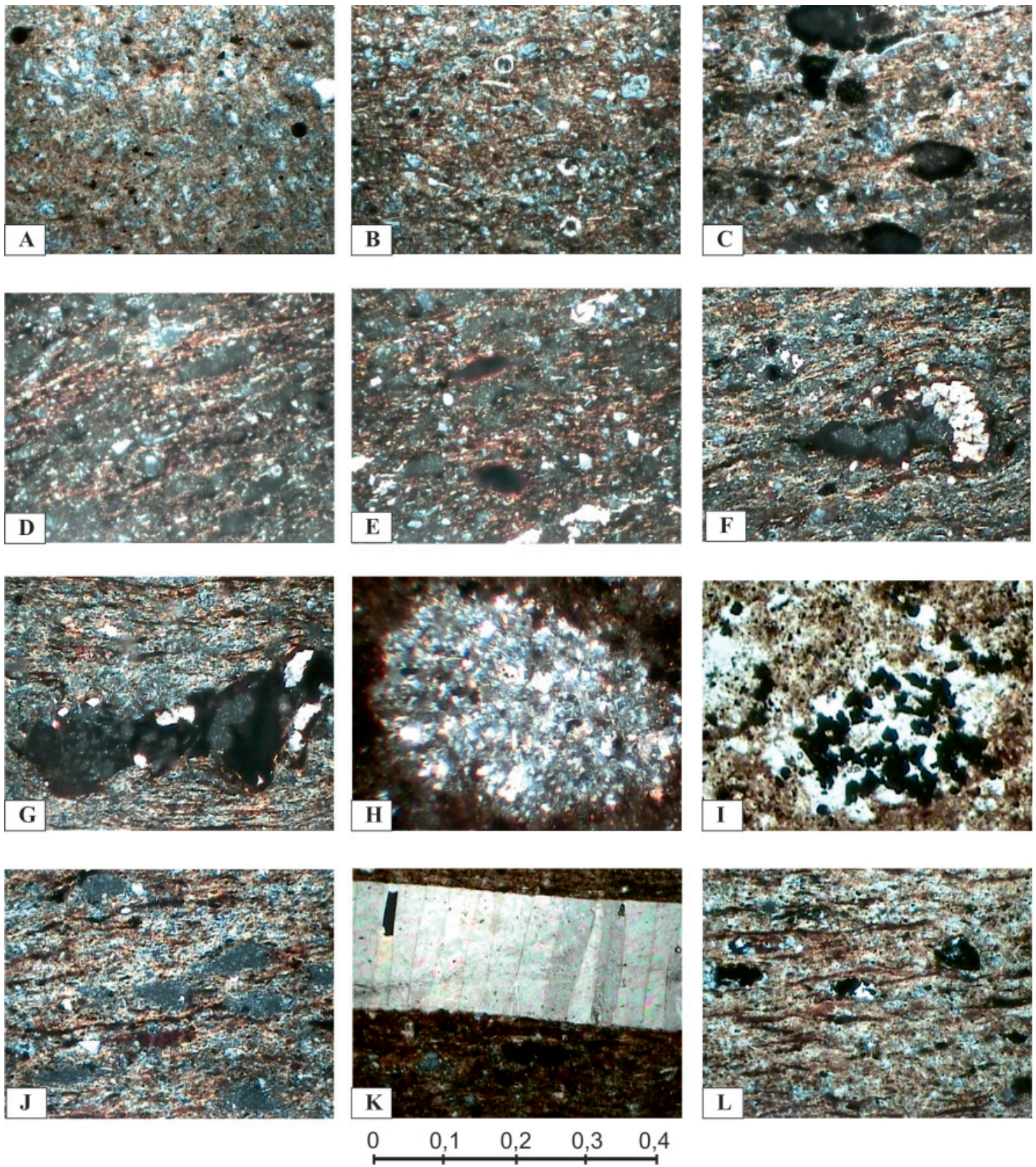

Рис. 2. Петрографические особенности литотипов баженовской свиты. Фото шлифов в скрещенных николях: A - литотип 1, алевропелитовая структура. ШЛ. 35. Скв. 2, Гл. 2818,8 м; В - литотип 2, спикулы губок, чешуйчатый агрегат. ШШл. 32. Скв. 2, Гл. 2815,2 м; С - литотип 3, радиолярии, волокнисто-чешуйчатый агрегат ШШл. 30. Скв. 2, Гл. 2814,0 м; D - литотип 4, кремнистый материал, волокна гидрослюд. Шл. 25. Скв. 2, Гл. 2811,8 м; E - литотип 4, тонко рассеянное и сгустковое органическое вещество. Шл. 10.Скв. 2, Гл. 2803,6 м; F- литотип 5-1, обломок окремненной и фосфатизированной фауны. Шл. 45. Скв. 1, Глуб. 3127,0 m; G - литотип 5-1, карбонатная сыпь по окремненному и фосфатизированному обломку фауны. Шл. 42. Скв. 1, Гл. 3125,4 м; H - литотип 5-2, ход илоеда с кремнисто-карбонатныл заполнением. ШІл. 46. Скв. 1, Гл. 3121,13 м; I - литотип 5-2, ход илоеда с пиритом. Шл. 4 (без анализатора). Скв. 2, Гл. 2800,4 м; J - литотип 5-3, чешуйчато-волокнистый агрегат. ШІл. 45. Скв. 1, Гл. 3125,9 м; K - литотип 5-4, остаток стебля криноидеи. Шл. 42.Скв. 1, Гл. 3124,25 м; L- литотип 6, волокнисточешуйчатое строение, пиритизированные раковины радиолярий. Шл. 38. Скв. 1, Глуб. $3121,13 \mathrm{~m}$

Fig. 2. Petrographic features of the Bazhenov suite lithotypes. Photo of the section is shown in crossed nicols: A - lithotype 1, aleuropelitic structure. Slide 35. Well 2, Depth 2818,8 m; B - lithotype 2, spicules of sponges, scaly aggregate. Slide 32. Well 2, Depth 2815,2 m; C-lithotype 3, radiolarians, fibrous-scaly aggregate. Slide 30. Well 2, Depth 2814,0 m; D - lithotype 4, siliceous material, hydromica fibers. Slide 25. Well 2, Depth 2811,8 m; E - lithotype 4, finely dispersed and clotted organic matter. Slide 10. Well 2, Depth 2803,6 m; F-lithotype 5-1, fragment of silicified and phosphatized fauna. Slide 45. Well 1, Depth 3127,0 m; G - lithotype 5-1, carbonate rash on silicified and phosphatized fragments of fauna. Slide 42. Well 1, Depth 3125,4 m; $\mathrm{H}$ - lithotype 5-2, the course of the ylode with siliceous-carbonate filling. Slide 46. Well 1, Depth 3121,13 m; I - lithotype 5-2, the course of the ylode with pyrite. Slide 4 (No analyzer). Well 2, Depth 2800,4 m; J - lithotype 5-3, scaly fibrous aggregate. Slide 45. Well 1, Depth $3125,9 \mathrm{~m} ; \mathrm{K}$ - lithotype 5-4, the remainder of the stalk of the crinoid. Slide 42. Well 1, Depth 3124,25 m; - lithotype 6, fibrous-scaly structure, pyritized shells of radiolarians. Slide 38. Well 1, Depth 3121,13 m 


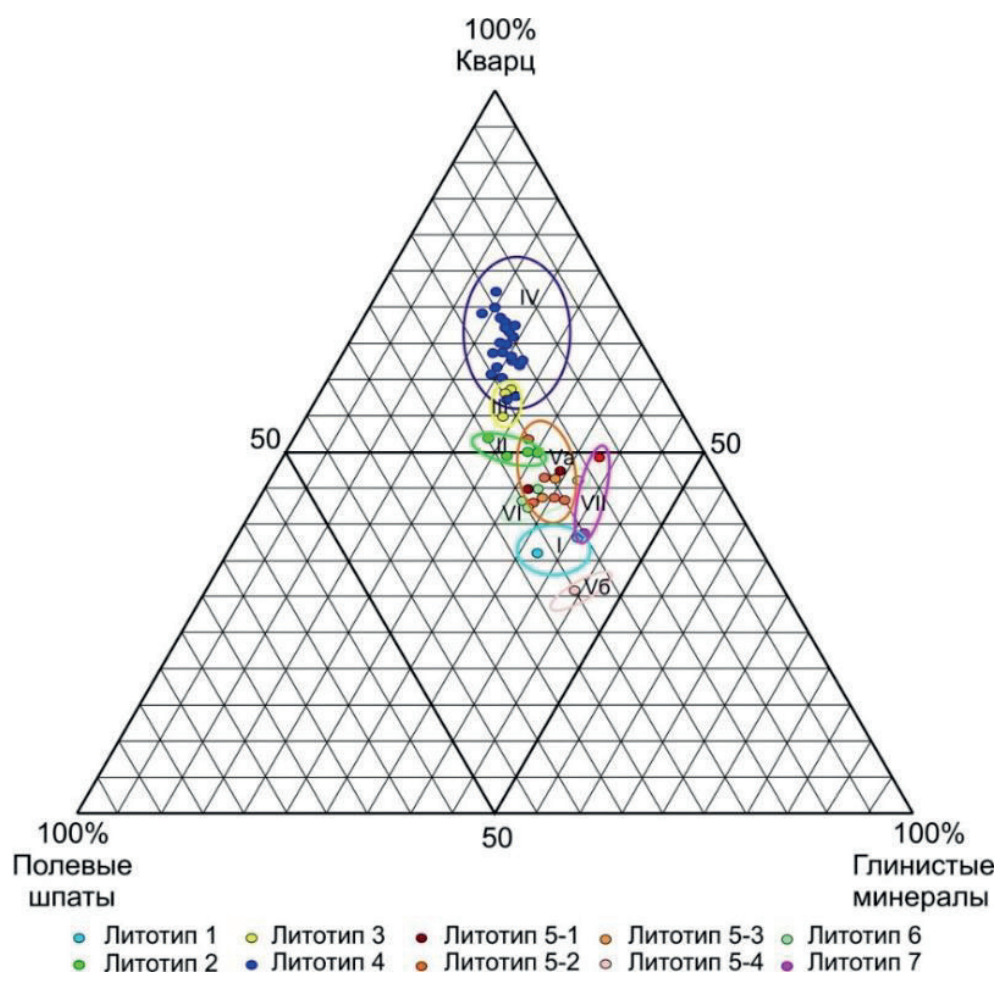

Рис. 3. Положение литотипов на треугольной диагралме состава породообразующих колпонентов баженовской свиты

Fig. 3. Lithotypes position on the triangle diagram of Bazhenov Suite rock-forming constituents composition

тигенным (слагающим раковины радиолярий) кварцем $(34,7 \ldots 34,9 \%)$.

Пирит $(3,5 . . .7,1 \%)$ рассеян в породе, приурочен к ходам илоедов, образует конкреции и псевдоморфозы по органическим остаткам. Встречаются единичные мелкие (менее 0,01 мм) неправильные и ромбоэдрические зерна доломита.

На треугольной диаграмме соотношения полевых шпатов, глинистых минералов и кварца (рис. 3) точки состава алеврито-силицитовых аргиллитов располагаются в поле I с высоким содержанием глинистого и полевошпатового материала и низким содержанием кварца.

Литотип 2 (рис. 2, В) - битулинозные силици то-аргиллиты с крелнистыли прослойкали и остаткали крелниевых водорослей - коричневочерные с редкими фосфатизированными онихитами и рострами белемнитов, немногочисленными коническими округло-уплощенными кремнистыми частично пиритизированными и карбонатизированными раковинами радиолярий, спикулами губок. Кремнистые прослойки прерывистые тонкие (менее 1 мм). Породы слабо пиритизированы $(2,1 \ldots 5,4 \%)$ иногда слабо карбонатизированы $(0 . .2,8 \%)$. Структура их пелитовая и лепидобластовая за счет одинаковой ориентировки чешуйчатых агрегатов слюдистых минералов.

Соотношение глинистой $(44,4 \ldots 49,3 \%$ ) и кремниевой $(47,6 \ldots 48,5 \%)$ составляющих в породах примерно одинаковое, поэтому на треугольной диаграмме (рис. 3) точки литотипа располагаются в поле II с содержанием кварца около 50 \% .
Повсеместно присутствует рассеянное тонко диспергированное и сгустковое гелефицированное с аморфной структурой органическое вещество бурого цвета, распределенное равномерно, послойно, приуроченное к внутренним полостям раковин радиолярий. Керн разбит трещинами, насыщен нефтью, обладает запахом, напоминающим запах керосина, имеет жирную поверхность, пачкает руки, оставляя на них маслянистую пленку.

Литотип 3 (рис. 2, С) - битулинозные силициты глинистые радиоляриевые - буровато-черные с неравномерной горизонтальной, линзовидной, полого-наклонной листоватой слоистостью, мелкими онихитами белемнитов, спикулами губок и слабо сохраненными раковинами радиолярий, раздробленными, растворенными, перекристаллизованными, иногда тонко пиритизированными, с рассеянной сыпью пирита $(2,9 \ldots 3 \%)$, иногда с пиритовыми конкреционными стяжениями. Породы в разной степени карбонатизированы: от 0,5 \% - в нижней, до 10,8 \% - в верхней части разреза.

В составе пород преобладает кремнистый $(49,2 \ldots 53,3 \%)$ материал над глинисто-гидрослюдистым $(37,1 . .43,2 \%)$ волокнисто-чешуйчатым. Фигуративные точки на диаграмме (рис. 3) располагаются в поле III, занимая промежуточное положение между фигуративными точками 2 и 4 литотипов.

Рассеянное органическое вещество равномерно распределено в матрице породы, окрашивая ее в бурый цвет, реже встречается в концентрированной форме, образуя сгустки и послойные скопления. 
Керн разбит субвертикальными и наклонными трещинами на крупные куски, на плоскостях наслоения отмечается кальцит. Породы насыщены нефтью, имеют характерный запах, напоминающий запах керосина, жирные на ощупь, оставляют маслянистую пленку на руках.

Литотип 4 (рис. 2, D, Е) - битулинозные силициты радиоляриевые с трубчатыли раковина ли и крелнистыли прослойкали - буровато-черные тонко отмученные с неотчетливой горизонтальной слойчатостью, конкрециями и послойными присыпками (до 0,8 cм толщиной) пирита, включениями ихтиофауны, ростров и фосфатизированных онихитов белемнитов, конусообразными трубчатыми раковинами (размерами по удлинению до 4 мм), раздробленными, растворенными и сильно перекристаллизованными кремнистыми скелетами радиолярий, спикулами губок.

В составе пород биогенный и слабо раскристаллизованный кремнистый материал $(49,9 . .66,7$ \%) преобладает над волокнистым глинисто-гидрослюдистым $(25,1 \ldots 38,4 \%)$. Пирит $(3,6 . .10,3 \%)$ присутствует в виде сыпи, псевдоморфоз по органогенным остаткам. Породы не карбонатизированы или содержат рассеянную сыпь кальцита и доломита $(0 . .2,6 \%)$, лишь в единичных прослоях содержание карбонатов возрастает до 4,5...9,6 \% в основном за счет кальцита в органогенных остатках. Самое низкое содержание полевых шпатов $(12,8 \%)$ и глинистых минералов в целом $(25,1 \%)$, максимальное соотношение кремнистого и глинистого материала $(72: 28)$ и очень высокое содержание пирита $(10,3 \%$ ) отмечено в образце 19 (глубина отбора 2808,93 м).

На треугольной диаграмме (рис. 3) точки литотипа обособляются в верхней части - поле IV.

Рассеянное органическое вещество бурого цвета насыщает породу, присутствует как в рассеянном, так и в концентрированном виде, образуя сгустки, часто ориентированные по наслоению, заполняет полости в раковинах радиолярий.

Керн расколот на послойные плитки, насыщен нефтью, имеет маслянистую поверхность и обладает сильным запахом нефти.

Лuтотип 5 (рис. $2, \mathrm{~F}-\mathrm{K}$ ) - битулинозные аргиллиты силииитовые радиоляриевые со следали биотурбации и остаткали криноидей - темно-серые однородные, с онихитами белемнитов, спикулами губок, иногда с обломками окремненной фауны (литотип 5-1, рис. 2, F, G); следами жизнедеятельности донных илоядных организмов (литотип 5-2, рис. Н, I); с тонкими (доли мм) прерывистыми кремнистыми прослойками, скоплениями радиолярий, высоким (до 10,3 \%) содержанием пирита (литотип 5-3, рис. 2 , J); с неокатанными обломками криноидей, сложенных полигональными (ячеи чашечек) и шестоватыми (стебли) агрегатами кальцита (литотип 5-4, рис. $2, \mathrm{~K}$ ), и мелких двустворчатых раковин. Породы сложены в разной степени раскристаллизованным кремнистым, чешуйчато-волокнистым глинисто-гидрослюди- стым, а в участках биотурбации беспорядочно распределенным пелитовым и мелкоалевритовым (заполняет ходы и норки) материалом.

Содержание кремнистого материала в породах непостоянно и колеблется от 26,5 до $44,9 \%$, глинистого - 41,6...59,8 \% . Породы пиритизированы $(6,3 \ldots 13,8 \%)$, в разной степени карбонатизированы $(1,4 \ldots 10,6 \%)$.

Фигуративные точки литотипа на диаграмме (рис. 3) сконцентрированы в поле Vб, лишь точка литотипа 5-4 смещена в сторону полевошпатовой и глинистой составляющих.

Породы насыщены бурым рассеянным органическим веществом. Повсеместно в них наблюдаются разно ориентированные трещины, отмечается нефтенасыщение.

Литотип 6 (рис. 2, L) - силицитовые аргиллиты радиоляриевые с остатками водорослей - темно-серые до черных, однородные, тонко отмученные, иногда послойно пиритизированные с пиритизированными органогенными обломками створчатых раковин, спикул губок, радиолярий, водорослей и редкими включениями фосфатизированных онихитов белемнитов. Структура пород лепидобластовая, образованная глинисто-слюдистым волокнистым агрегатом, между волокнами которого располагаются растворенные и сложенные кварцем и халцедоном пиритизированные раковины радиолярий, спикулы губок, в разной степени раскристаллизованный кремнистый материал, остатки водорослей, рассеянное бурое органическое вещество, пирит, терригенные обломки кварца и полевых шпатов.

Содержание глинистого материала $(47,9 . .51,9 \%)$ превалирует над содержанием кремнистого $(37,1 . .40,1 \%)$, содержание пирита - 6,3...8,9 \% , кальцита - 2,3...3,9\% .

Литотип 7 - силицит-глинисто-карбонатные nороды - под микроскопом не изучался. Согласно РФА, породы сложены на $12 . .24,3$ \% кремнистым и на $18,9 \ldots 24,8 \%$ глинистым материалом, $47,6 \ldots 65,5 \%$ приходится на карбонаты и в незначительном количестве присутствует пирит $3,3 . . .3,5 \%$.

\section{Обсуждение результатов}

Формирование уникального баженовского коллектора обусловлено литогенетическими (седиментогенными, диагенетическими, катагенетическими) и тектоническими факторами.

Согласно общепринятым представлениям, формирование осадков баженовской свиты осуществлялось на фоне позднеюрской трансгрессии моря и медленного опускания дна морского бассейна в условиях теплого и влажного климата, способствовавшего развитию морских организмов $[5,12,13]$.

На территории исследования на большем протяжении времени формирования отложений баженовской свиты осадконакопление осуществлялось при стабильно низкодинамичном застойном режиме седиментации в относительно глубоководных мор- 
ских условиях восстановительной геохимической среды. Об этом свидетельствуют толщина относительно однородных осадков, их тонкодисперсный характер, остатки морской фауны, прежде всего, радиолярий, и постоянное присутствие, а иногда и повышенное содержание пирита - индикаторного минерала восстановительной обстановки.

Глинистые илы, накопившиеся в георгиевское время (литотип 1) в условиях слабого насыщения придонных вод кислородом, с течением времени сменялись более глубоководными осадками эпиконтинентального моря - радиоляриевыми илами, обогащенными кремнистым материалом биогенного и химического происхождения (литотипы 2 и 3 ). В ходе дальнейшего осадконакопления в составе донных осадков кремнистая составляющая постепенно стала преобладать (литотип 4), что обусловлено углублением бассейна седиментации и менее активным терригенным сносом по мере удаления от береговой линии. Инверсионной точкой трансгрессивно-регрессивного цикла седиментации, вероятно, послужило время накопления осадков, представленных образцом 19 с максимальным соотношением кремнисто-глинистой составляющей и высоким содержанием пирита. С этого момента осадки вновь постепенно обогащаются глинистыми компонентами, и в первую очередь терригенными полевыми шпатами.

Увеличение доли кремнистого материала и пирита может быть объяснено также с позиций усиления тектонической активности в титон-берриасское время, подтока вещества по дизъюнктивным нарушениям [14] или поступлением вулканогенного материала [15].

Отступление баженовского моря осуществлялось дискретно, что выразилось в разнообразии пород, слагающих литотип 5, знаменующих колебательный характер условий седиментации: от уменьшения глубины осадконакопления со слабым насыщением кислородом придонных вод, биотурбацией осадка донными животными (литотип 5-2) и криноидными остатками (литотип 5-4) до ее увеличения и более восстановительных условий с формированием прослоев, обогащенных радиоляриями и пиритом (литотип 5-3).

Наконец, в менее глубоководных условиях происходило формирование литотипа 6 , в котором существенно увеличено содержание глинистого и алевритового материала и широко распространены остатки водорослей.

Карбонатность пород обусловлена присутствием обломков фауны, имеющей кальцитовый скелет, а также химическим осаждением, что выразилось в рассеянной минерализации и в замещении фаунистических остатков.

Практически все литотипы содержат в повышенном количестве рассеянное и концентрированное сапропелевое органическое вещество и могут быть в полной мере отнесены к разряду нефтематеринских. Биопродуцентами явились планктонные (радиолярии и др.), бентосные (водоросли, мор- ские лилии и др.) и нектонные (белемниты и др.) организмы, остатки которых постоянно встречаются в породах. Наиболее насыщены рассеянным органическим веществом породы литотипа 4 , они же обогащены кремнистым материалом и раковинами радиолярий. Сохранность органического вещества обеспечивалась тонкодисперсной структурой пород и благоприятными условиями восстановительной среды. На положительное влияние восстановительных условий на сохранность органического вещества в нефтяных сланцах указывается в ряде работ [16-19].

Глубина погружения баженовской свиты на территории исследования достигает 2788...2815 м (скв. 4) и 3118...3145 м (скв. 3). Согласно И.В. Гончарову [8, 9], уровень катагенеза органического вещества соответствует в этом районе Нюрольского мегабассейна мезокатагенезу градации $\mathrm{MK}_{2}$ и породы находятся в главной зоне нефтенакопления, по В.И. Исаеву и др. [20], они располагаются в очаге интенсивной генерации баженовской нефти.

До настоящего времени существует несколько точек зрения на тип коллектора в аргиллитах баженовской свиты. Баженовский коллектор сформировался как результат межслоевого пространства: (микро-) плитчатости, слойчатости и листоватости [5], часто его природу определяют, как трещинную [6], трещинно-поровую и поровую [21]; в карбонатных породах развит каверновый тип коллектора [22].

В изучаемом разрезе карбонатные породы распространены в нижней части и служат экраном, удерживающим углеводороды внутри баженовской свиты, они не растворены и не содержат пустот. Аргиллиты силицитовые, силициты и глинистые силициты продуктивного разреза обладают видимым межслоевым и трещинным пространством. Вместе с тем, с учетом только этих типов пустот, трудно объяснить наличие нефти в текстурно-однородных и не трещиноватых породах.

Обзор литературы по изучению эволюции пустотного пространства в нефтематеринских толщах $[1,23-28]$ показывает, что вопрос формирования коллекторских свойств в битуминозных отложениях, вступивших в главную фазу нефтеобразования, далеко не простой и требует тщательного анализа.

$\mathrm{C}$ нашей точки зрения, формирование пустотного пространства в аргиллитах баженовской свиты следует начинать рассматривать с момента седиментации.

Насыщенные водой тонкодисперсные илы баженовской свиты, вероятно, обладали высокой седиментогенной пористостью. В процессе диагенеза за счет уплотнения и оттока воды из осадка, а также при осаждении диагенетических минералов (кремнистых, пирита, карбонатов и др.) эта пористость значительно сокращалась, а возможно, была уничтожена.

Наличие в породах органогенных остатков способствовало формированию биопустотной пористости, образованной при микробиальном разложе- 
нии организмов в раннем диагенезе. Этот тип пористости зачастую сохранялся вплоть до катагенеза. Доказательством чему является повсеместная приуроченность органического вещества к внутренним полостям раковин радиолярий, спикул губок, макрофаунистических остатков.

В катагенезе в процессе термического созревания и термокаталитического преобразования органического вещества, особенно в условиях главной фазы нефтеобразования $\left(\mathrm{MK}_{1}-\mathrm{MK}_{3}\right)$, на которой находятся в настоящее время изучаемые породы $\left(\mathrm{MK}_{2}\right)$, пустотное пространство формировалось за счет деструкции твердого органического вещества (керогена). Известно, что при генерации нефти происходит существенное преобразование молекулярной структуры ОВ, сопровождающееся выделением газообразных $\left(\mathrm{CO}_{2}, \mathrm{CH}_{4}, \mathrm{NH}_{3}, \mathrm{~N}_{2}, \mathrm{H}_{2} \mathrm{~S}\right)$ и жидких продуктов (нефтяные углеводороды и вода) и потерей массы исходного органического вещества. В результате объем твердой фазы органического вещества сокращается, а жидкой и газообразной, напротив, увеличивается. Как следствие этого, за счет уменьшения объема органического вещества образуется дополнительное свободное поровое пространство (так называемая органическая пористость), которое образует эффективную сеть пор и служит хранилищем генерированных углеводородов, удерживая их внутри материнской свиты.

В дальнейшем оставшиеся незалеченными в диагенезе биогенные поры и образованные в катагенезе органические поры расширяются вследствие давления на них выделившихся газообразных и жидких продуктов, образуются подновленные (доработанные) поры и коллектор тонкопорового типа с равномерно распределенным пустотным пространством.

С этим же процессом связывается и подновление (модификация) пор в минеральной части коллектора (в трещиноватых зернах, зернах с внутризерновыми порами), которые заполняет газ и нефть. При этом проницаемость пород во время генерации углеводородов может изменяться от микро- и наноуровня до уровня Дарси.

В ходе дальнейшего преобразования органического вещества и возрастания давления до критического происходил флюидоразрыв пород с образованием межслоевых и внутрислоевых трещин [5],

\section{СПИСОК ЛИТЕРАТУРЫ}

1. Liu K., Ostadhassan M. Microstructural and geomechanical analysis of Bakken shale at nanoscale // Journal of Petroleum Science and Engineering 2017. - V. 153. - P. 133-144.

2. Evaluation of Eocene source rock for potential shale oil and gas generation in north Cambay Basin, India / S. Kumar, K. Ojha, R. Bastia, K. Garg, S. Das, D. Mohanty // Marine and Petroleum Geology. - 2017. - V. 88. - P. 141-154.

3. Effects of organic matter and mineral compositions on pore structures of shales: A comparative study of lacustrine shale in Ordos Basin and Marine Shale in Sichuan Basin, China / X. Tang, Z. Jiang, S. Jiang, Z. Li, Y. Peng, D. Xiao, F. Xing // Energy Exploration and Exploitation. - 2018. - V. 36. - № 1. - P. 28-42. аналогично указанным в ряде экспериментальных работ [24-27]. Миграция осуществлялась преимущественно внутри баженовской свиты, надежно перекрытой снизу и сверху глинистыми и карбонатно-глинистыми флюидоупорами георгиевской и куломзинской свит. Следы миграции нефти неоднократно описывались в работах $[5,6,14,15,18$, $29,30]$. Увеличение объема пустотного пространства баженитов при их погружении на глубину более 2000 м может составлять от 4-5 до $12 \%$ и более [31]. Вместе с тем трещинная проницаемость пород, связанная с процессом флюидоразрыва, увеличивается незначительно, до уровня миллидарси [25], из-за смыкания их стенок в процессе дальнейшего катагенетического уплотнения.

Вторичная трещинная пустотность, проявленная в расколе пород на куски и связанная с системой разно ориентированных трещин, обусловлена проявлением тектонических процессов $[14,15,18,31]$.

Таким образом, изученный баженовский коллектор сформирован в результате различных (первичных и вторичных) процессов и имеет смешанное происхождение.

\section{Заключение}

Нефтенасыщенные отложения баженовской свиты на юго-востоке Нюрольского осадочного бассейна (Тамратская впадина) имеют неоднородный литологический состав и представлены битуминозными силицито-аргиллитами с кремнистыми прослойками и остатками кремниевых водорослей; битуминозными силицитами глинистыми радиоляриевыми; битуминозными силицитами радиоляриевыми с трубчатыми раковинами и кремнистыми прослойками; битуминозными аргиллитами силицитовыми радиоляриевыми со следами биотурбации и остатками криноидей.

Баженовский коллектор имеет смешанное происхождение, пустотное пространство в нем формировалось в диагенезе, катагенезе и эпигенезе и представлено седиментогенными и диагенетическими биопустотами; катагенетическими порами, образованными за счет термокаталитического преобразования органического вещества при газонефтегенерации; катагенетическими (межслоевыми и внутрислоевыми) и тектоническими (межслоевыми и сквозными) трещинными пустотами.

4. Origin of organic matter and paleo-sedimentary environment reconstruction of the Triassic oil shale in Tongchuan City, southern Ordos Basin (China) / D. Li, R. Li, Z. Zhu et al. - Fuel. - 2017. V. 208. - P. 223-235.

5. Трофимук А.А., Карогодин Ю.Н. Баженовская свита - уникальный природный резервуар // Геология нефти и газа. 1981. - № 4. - С. 29-33.

6. Баженовская свита. Общий обзор, нерешенные проблемы / Г.А. Калмыков, Н.С. Балушкина, И.С. Афанасьев, Е.В. Гаврилова, Е.М. Бирун // Российские нефтегазовые технологии. 2011. - № 25. - C. 24-36.

7. Районирование мегавпадин юго-востока Западной Сибири по плотности ресурсов сланцевой нефти тогурской и баженовской 
материнских свит / В.И. Исаев, Г.А. Лобова, А.К. Мазуров, В.И. Старостенко, А.Н. Фомин // Геология нефти и газа. 2018. - № 1. - C. 15-39.

8. Катагенез органического вещества пород баженовской свиты юго-востока Западной Сибири (Томская область) / И.В. Гончаров, В.В. Самойленко, Н.В. Обласов, С.В. Фадеева // Нефтяное хозяйство. - 2013. - № 10. - С. 32-37.

9. Гончаров И.В., Носова С.В., Самойленко В.В. Генетические типы нефтей Томской области // Химия нефти и газа: матер. V Междунар. конф. - Томск: СО РАН, 2003. - С. 10-14.

10. Распределение органического вещества в породах баженовского горизонта (Западная Сибирь) / А.Э. Конторович, Е.В. Пономарева, Л.М. Бурштейн и др. // Геология и геофизика. 2018. - Т. 59. - № 3. - С. 357-371.

11. Номоконова Г.Г. Геофизическая характеристика и нефтеносность баженовской свиты // Геофизические методы при разведке недр: материалы Всероссийской научно-практической конференции с международным участием, посвященной 70-летию основания в Томском политехническом институте кафедры «Геофизические методы поисков и разведки месторождений полезных ископаемых» - Томск, 20-23 апреля 2016. Томск: Изд-во ТПУ, 2016. - С. 154-157.

12. Захаров В.А. Условия формирования волжско-берриасской высокоуглеродистой баженовской свиты по данным палеоэкологии // Эволюция биосферы и биоразнообразия. - М.: Товарищество научных изданий КМК, 2006. - С. 552-568.

13. Shaminova M., Rychkova I., Sterzhanova U. Paleogeographic and litho-facies formation conditions of MidUpper Jurassic sediments in S-E Western Siberia (Tomsk Oblast) // IOP Conference Series: Earth and Environmental Science. Problems of Geology and Subsurface Development. - 2016. - V. 43. - 012001, 5 p.

14. Предтеченская Е.А., Злобина 0.Н. Литолого-фациальные особенности баженовской свиты как «промежуточного» коллектора углеводородов в зонах дизъюнктивных нарушений // Сoвременные проблемы седиментологии в нефтегазовом инжиниринге: труды III Всероссийского научно-практического седиментологического совещания. - Томск, 10-12 апреля 2017. Томск: Изд-во ЦППС НД, 2017. - С. 113-122.

15. Петрография и минералогия глин аномально люминесцирующих прослоев баженовской свиты Западно-Сибирского осадочного бассейна / М.В. Шалдыбин, В.В. Крупская, А.В. Глотов и др. // Нефтяное хозяйство. - 2018. - № 2. - С. 36-40.

16. Organic geochemical and petrographic characteristics of the oil shales in the Lajjun area, Central Jordan: Origin of organic matter input and preservation conditions / M.H. Hakimi, W. H. Abdullah, M. Alqudah et al. - Fuel. - 2016. - V. 181. - P. 34-45.

17. Geochemical characteristics, redox conditions, and organic matter accumulation of marine oil shale from the Changliang Mountain area, northern Tibet, China / S. Zeng, J. Wang, W. Chen, C. Xinglei, F. Dong, D. Wang, C. Song, Z. Wang // Marine and Petroleum Geology. - 2015. - V. 64. - P. 203-221.

18. The mineralogy of the clayey-silty siliceous rocks in the Bazhenov Shale Formation (Upper Jurassic) in the west Siberian Basin, Russia: The role of diagenesis and possible implications for their exploitation as an unconventional hydrocarbon reservoir / M.V. Shaldybin, Y.M. Lopushnyak, I.V. Goncharov, M.J. Wilson, L. Wilson, B.G. Mendis // Applied Clay Science. - 2017. № 136. - P. 75-89.

19. Occurrence of organic matter-rich deposits (Middle Jurassic to Lower Cretaceous) from Qalikuh locality, Zagros Basin, South-West of Iran: A possible oil shale resource / A. Rasouli, A. Shekarifard, F.J. Farahani, M.V. Kök, M. Daryabandeh, M. Rashidi // International Journal of Coal Geology. - 2015. - V. 143. - P. 34-42.

20. Районирование баженовской свиты и клиноформ неокома по плотности ресурсов сланцевой и первично-аккумулированной нефти (на примере Нюрольской мегавпадины) / В.И. Исаев, Г.А. Лобова, А.К. Мазуров, А.Н. Фомин, В.И. Старостенко // Геофизический журнал. - 2016. - № 3. - Т. 38. - С. 29-51.

21. Куляпин П.С., Соколова Т.Ф. Прогноз коллекторов в разрезе баженовской свиты по материалам керна и геофизических исследований скважин // Известия Томского политехнического университета. - 2015. - Т. 326. - № 1. - С. 118-133.

22. Соболева Е.В. Формирование состава нефтей пласта $Ю_{0}$ баженовской свиты Салымского месторождения // Георесурсы. 2017. - № 5. - C. 144-154.

23. Factors impacting on oil retention in lacustrine shale: Permian Lucaogou Formation in Jimusaer Depression, Junggar Basin / H. Pang, X.-q. Pang, L. Dong, X. Zhao // Journal of Petroleum Science and Engineering. - 2018. - V. 163. - P. 79-90.

24. Pore-types and pore-network evolution in Upper Devonian-Lower Mississippian Woodford and Mississippian Barnett mudstones: Insights from laboratory thermal maturation and organic petrology / L.T. Ko, S.C. Ruppel, R.G. Loucks, P.C. Hackley, T. Zhang, D. Shao // International Journal of Coal Geology. 2018. - V. 190. - P. 2-28.

25. Burnham A.K. Porosity and permeability of Green River oil shale and their changes during retorting // Fuel. - 2017. - V. 203. P. 208-213.

26. Characterization of oil shale pore structure before and after pyrolysis by using X-ray micro CT / P. Tiwari, M. Deo, C.L. Lin, J.D. Miller // Fuel. - 2013. - V. 107. - P. 547-554.

27. Formation and development of the pore structure in Chang 7 member oil-shale from Ordos Basin during organic matter evolution induced by hydrous pyrolysis / L. Sun, J. Tuo, M. Zhang, C. Wu, Z. Wang // Fuel. - 2015. - V. 158. - P. 549-557.

28. Evaluation of the porous structure of Huadian oil shale during pyrolysis using multiple approaches / F.T. Bai, Y.H. Sun, Y.M. Liu, M.Y. Guo // Fuel. - 2017. - V. 187. - P. 1-8.

29. Specific features of Bazhenov suite sediments in south-eastern Nurolsk sedimentary basin (Tomsk Oblast) / N. Nedolivko, T. Perevertailo, Cunyi Li, R. Abramova // Problems of Geology and Subsurface Development: XIX International Scientific Symposium in honor of Academician M.A. Usov. IOP Conf. Series: Earth and Environmental Science 27. - Tomsk, Russia, 6-10 April 2015. - 012014, $6 \mathrm{p}$.

30. Недоливко Н.М., Ежова А.В. Литогенетические типы отложений баженовской свиты на Южно-Майском локальном поднятии по результатам изучения керна скв. 413 (Томская область) // Геология и минерально-сырьевые ресурсы Сибири. - 2015. № 4. - C. 40-47.

31. Предтеченская Е.А., Злобина 0.Н. 0 вещественном составе и механизме формирования «промежуточного коллектора» в доманикитах в зонах вертикальной миграции флюидов (на примере баженовской свиты Западной Сибири) // 5-е Кудрявцевские Чтения: Всероссийская конференция по глубинному генезису нефти и газа. - Москва, 17-19 октября 2016. - М.: Издво ЦГЭ, 2016. - 5 с.

Поступила 06.10.2018 г.

\section{Информация об авторах}

Недоливко H.M., кандидат геолого-минералогических наук, доцент отделения геологии Инженерной школы природных ресурсов Национального исследовательского Томского политехнического университета.

Перевертайло Т.Г., кандидат геолого-минералогических наук, доцент отделения геологии Инженерной школы природных ресурсов Национального исследовательского Томского политехнического университета. 


\title{
LITHOLOGICAL AND PETROGRAPHIC CHARACTERIZATION OF BAZHENOV SUITE RESERVOIR ROCKS IN THE SOUTH-EAST OF THE WESTERN-SIBERIAN PROVINCE (TOMSK REGION)
}

\author{
Natalya M. Nedolivko',
}

nedolivko@tpu.ru

\author{
Tatyana G. Perevertaylo', \\ ptg@tpu.ru \\ National Research Tomsk Polytechnic University,
30, Lenin Avenue, Tomsk, 634050, Russia.
}

The relevance of this research comes in response to the need to expand the resources of Western Siberia including Tomsk region, by the development of hard-to-recover oil reserves concentrated in the Bazhenov Suite (Tithonian-Berriasian).

The aim of the research is to reveal the features of the lithologic composition and structure of the Bazhenov reservoir rocks across the potentially prospective oil-producing Tomsk region.

Object: Bazhenov Suite bituminous deposits discovered by drilling at a local elevation in the Tamrat Basin (Nyurol' sedimentary basin), the Pudinsky oil-and-gas-bearing region of the West Siberian oil and gas province (Tomsk Oblast), where an oil inflow was obtained. Methods: geophysical studies, macroscopy core description, petrographic and $X$-ray analyzes.

Results. The paper introduces spatial distribution of decomposed rocks - oil and gas reservoirs - identified throughout the productive interval of the Bazhenov Suite. The study provides a detailed geophysical and petrographic description of rocks as well as their textural and compositional characteristics. Authors divide all rocks into seven lithotypes: 1) aleurit-silicitic argillites with rare tubicolous shells and "mud eater» fossils; 2) bituminous silicitic argillites with silicious bands and diatoms traces; 3) bituminous radiolarian argillic silicites; 4) bituminous radiolarian silicites with tubicolous shells and silicious bands; 5) bituminous radiolarian argillic silicites marked by bioturbation and crinoid traces; 6) radiolarian silicitic argillites with algae traces; 7) silicitic argillic carbonates. It was found that the accumulation of Bazhenov sediments was controlled by a low-dynamic stagnant sedimentation regime in relatively deep-sea conditions of the reducing geochemical environment. There is a correlation between both the mineral composition and the content of sapropelic organic matter with the transgressive-regressive sedimentation cyclicity: the $4^{\text {th }}$ lithotype is the most enriched in siliceous material and organic matter, and the maximum amount of these components occurs at the point of inversion of the transgressive-regressive cycle. The Bazhenov collector having a mixed genesis was formed during the multi-stage lithogenesis (sedimentogenesis-catagenesis) and poststadial processes. The void space is represented by ultrathin bio-voids and pores as well as by both interlayer and intralayer fractures.

\section{Key words:}

Nyurol' basin, Western Siberia, Tomsk region, Tithonian-Berriasian, Bazhenov suite,

bituminous argillite, oil source rocks, lithotype, reservoir rock.

\section{REFERENCES}

1. Liu K., Ostadhassan M. Microstructural and geomechanical analysis of Bakken shale at nanoscale. Journal of Petroleum Science and Engineering, 2017, vol. 153, pp. 133-144.

2. Kumar S., Ojha K., Bastia R., Garg K., Das S., Mohanty D. Evaluation of Eocene source rock for potential shale oil and gas generation in north Cambay Basin, India. Marine and Petroleum Geology, 2017, vol. 88, pp. 141-154.

3. Tang X., Jiang Z., Jiang S., Li Z., Peng Y., Xiao D. \& Xing F. Effects of organic matter and mineral compositions on pore structures of shales: A comparative study of lacustrine shale in Ordos Basin and Marine Shale in Sichuan Basin, China. Energy Exploration and Exploitation, 2018, vol. 36, no. 1, pp. 28-42.

4. Li D., Li R., Zhu Z. Wu X., Cheng J., Liu F., Zhao B. Origin of organic matter and paleo-sedimentary environment reconstruction of the Triassic oil shale in Tongchuan City, southern Ordos Basin (China). Fuel, 2017, vol. 208, pp. 223-235.

5. Trofimuk A.A., Karogodin Yu.N. Bazhenov suite is the unique natural reservoir. Geology of oil and gas, 1981, no. 4, pp. 29-33. In Rus.

6. Kalmykov G.A., Balushkina N.S., Afanasev I.S., Gavrilova E.V., Birun E.M. Bazhenovskaya svita. Obshchy obzor, nereshennye problem [Bazhenov suite. General review. Unsolved problems]. Rossiyskie neftegazovye tekhnologii, 2011, no. 25, pp. 24-36.

7. Isaev V.I., Lobova G.A., Mazurov A.K., Starostenko V.I., Fomin A.N. Zoning of mega-depressions by shale oil genegation density of Togur and Bazhenov source suites in the southeast of
Western Siberia. Oil and gas geology, 2018, no. 1, pp. 15-39. In Rus.

8. Goncharov I.V., Samoylenko V.V., Oblasov N.V., Fadeeva S.V. Catagenesis of organic matter of Bazhenov Formation rocks in the south-east of West Siberia (Tomsk region). Oil industry, 2013, no. 10, pp. 32-37. In Rus.

9. Goncharov I.V., Nosova S.V., Samoylenko V.V. Geneticheskie tipy neftey Tomskoy oblasti [Genetic types of oil in Tomsk region]. Khimiya nefti i gaza. Materialy V Mezhdunarodnoy konferentsii [Chemistry of oil and gas. Proc. of International conference]. Tomsk, SO RAN Publ., 2003. pp. 10-14.

10. Kontorovich A.E., Ponomareva E.V., Burshtein L.M., Glinskikh V.N., Kim N.S., Kostyreva E.A., Pavlova M.A., Rodchenko A.P., Yan P.A. Distribution of organic matter in rocks of the Bazhenov horizon (West Siberia). Geology and Geophysics, 2018, vol. 59, no. 3, pp. 285-298. In Rus.

11. Nomokonova G.G. Geofizicheskaya kharakteristika i neftenosnost bazhenovskoy svity [Geophysical characteristic and oil-bearing feature of Bazhenov suite]. Geofizicheskie metody pri razvedke nedr. Materialy Vserossiyskoy nauchno-prakticheskoy konferentsii s mezhdunarodnym uchastiem, posvyashchennoy 70-letiyu osnovaniya $v$ Tomskom politekhnicheskom institute kafedry «Geofizicheskie metody poiskov i razvedki mestorozhdeniy poleznykh iskopaemykh» [Geophysical techniques at exploration. Proc. Of the All-Russian scientific conference with international participation, devoted to the $70^{\text {th }}$ anniversary of foundation of the department «Geophysical methods of search and exploration of na- 
tural recourse fields» at Tomsk polytechnic institute]. Tomsk, 20-23 April 2016. Tomsk, TPU Publ. house, 2016. pp. 154-157.

12. Zakharov V.A. Usloviya formirovaniya volzhsko-berriasskoy vysokouglerodistoy bazhenovskoy svity po dannym paleoekologii [Conditions of formation of volzhsko-berriasskaya high-carbon bazhenov suite by the data of paleoecology]. Evolyutsiya biosfery i bioraznoobraziya [Evolution of biosphere and biological diversity]. Moscow, Tovarishchestvo nauchnykh izdaniy KMK Publ., 2006. pp. 552-568.

13. Shaminova M., Rychkova I., Sterzhanova U. Paleogeographic and litho-facies formation conditions of MidUpper Jurassic sediments in S-E Western Siberia (Tomsk Oblast). IOP Conference Series: Earth and Environmental Science. Problems of Geology and Subsurface Development, 2016, vol. 43, 012001, 5 p.

14. Predtechenskaya E.A., Zlobina 0.N. Litologo-fatsialnye osobennosti bazhenovskoy svity kak «promezhutochnogo" kollektora uglevodorodov v zonakh dizyunktivnykh narusheniy [Lithological and facial features of bazhenov suite as «intermediate» header of hydrocarbons in disjunctive fault areas]. Sovremennye problemy sedimentologii v neftegazovom inzhiniringe. Trudy III Vserossiyskogo nauchno-prakticheskogo sedimentologicheskogo soveshchaniya [Current problems in sedimentology in oil-and-gas engineering. Proc. of the III All-Russian scientific sedimentological meeting]. Tomsk, 10-12 April 2017. Tomsk, CPPS ND Publ., 2017. pp. 113-122.

15. Shaldybin M.V., Krupskaya V.V., Glotov A.V., Dorieva O.V., Goncharov I.V., Samoylenko V.V., Deeva E.S., Lopushnyak Yu.M., Bether O.V., Zakusin S.V. Petrography and clay mineralogy of anomaly luminescent layers in Bazhenov suite of Western Siberia sedimentary basin. Oil industry, 2018, no. 2, pp. 36-40. In Rus.

16. Hakimi M.H., Abdullah W.H., Alqudah M., Makeen Y.M. Organic geochemical and petrographic characteristics of the oil shales in the Lajjun area, Central Jordan: Origin of organic matter input and preservation conditions. Fuel, 2016, vol. 181, pp. 34-45.

17. Zeng S., Wang J., Chen W., Xinglei C., Dong F., Wang D., Song C., Wang Z. Geochemical characteristics, redox conditions, and organic matter accumulation of marine oil shale from the Changliang Mountain area, northern Tibet, China. Marine and Petroleum Geology, 2015, vol. 64, pp. 203-221.

18. Shaldybin M.V., Lopushnyak Y.M., Goncharov I.V., Wilson M.J., Wilson L., Mendis B.G. The mineralogy of the clayey-silty siliceous rocks in the Bazhenov Shale Formation (Upper Jurassic) in the west Siberian Basin, Russia: The role of diagenesis and possible implications for their exploitation as an unconventional hydrocarbon reservoir. Applied Clay Science, 2017, no. 136, pp. $75-89$.

19. Rasouli A., Shekarifard A., Farahani F.J., Kök M.V., Daryabandeh M., Rashidi M. Occurrence of organic matter-rich deposits (Middle Jurassic to Lower Cretaceous) from Qalikuh locality, Zagros Basin, South-West of Iran: a possible oil shale resource. In ternational Journal of Coal Geology, 2015, vol. 143, pp. 34-42.

20. Isaev V.I., Lobova G.A., Mazurov A.K., Fomin A.N., Starostenko V.I. Zoning of the Bazhenov suite and clinoforms of Neocomian according to the density resources of shale and primaryly-ac- cumulated oil (Nurol megadepression as an example). Geophysical journal, 2016, vol. 38, no. 3, pp. 29-51. In Rus.

21. Kulyapin P.S., Sokolova T.F. Reservoir identification in the Bazhenov Formation from well log and core data. Bulletin of the Tomsk Polytechnic University, 2015, vol. 326, no. 1, pp. 118-133. In Rus.

22. Soboleva E.V. Formation of oil composition of the $\mathrm{Yu}_{0}$ Bazhenov formation, Salym oil field. Georesursy, 2017, no. 5, pp. 144-154. In Rus.

23. Pang H., Pang X.-q., Dong L., Zhao X. Factors impacting on oil retention in lacustrine shale: Permian Lucaogou Formation in Jimusaer Depression, Junggar Basin. Journal of Petroleum Science and Engineering, 2018, vol. 163, pp. 79-90.

24. Ko L.T., Ruppel S.C., Loucks R.G., Hackley P.C., Zhang T., Shao D. Pore-types and pore-network evolution in Upper Devonian-Lower Mississippian Woodford and Mississippian Barnett mudstones: Insights from laboratory thermal maturation and organic petrology. International Journal of Coal Geology, 2018, vol. 190, pp. 2-28.

25. Burnham A.K. Porosity and permeability of Green River oil shale and their changes during retorting. Fuel, 2017, vol. 203, pp. 208-213.

26. Tiwari P., Deo M., Lin C.L., Miller J.D. Characterization of oil shale pore structure before and after pyrolysis by using X-ray micro CT. Fuel, 2013, vol. 107, pp. 547-554.

27. Sun L., Tuo J., Zhang M., Wu C., Wang Z. Formation and development of the pore structure in Chang 7 member oil-shale from Ordos Basin during organic matter evolution induced by hydrous pyrolysis. Fuel, 2015, vol. 158, pp. 549-557.

28. Bai F.T., Sun Y.H., Liu Y.M., Guo M.Y. Evaluation of the porous structure of Huadian oil shale during pyrolysis using multiple approaches. Fuel, 2017, vol. 187, pp. 1-8.

29. Nedolivko N., Perevertailo T., Li Cunyi and Abramova R. Specific features of Bazhenov suite sediments in south-eastern $\mathrm{Nu}$ rolsk sedimentary basin (Tomsk Oblast). XIX International Scientific Symposium in honor of Academician M.A. Usov «Problems of Geology and Subsurface Development». IOP Conf. Series: Earth and Environmental. Science Tomsk, Russia, 6-10 April 2015. Vol. 27, 012014, 6 p.

30. Nedolivko N.M., Eshova A.V. Lithogenetic deposit types of the Bazhenov formation in the South-Maya local high from core data acquired in the well no. 413 (Tomsk Region). Geology and mineral resources of Siberia, 2015, no. 4, pp. 40-47. In Rus.

31. Predtechenskaya E.A., Zlobina 0.N. 0 veshchestvennom sostave i mekhanizme formirovaniya "promezhutochnogo kollektora" v domanikitakh v zonakh vertikalnoy migratsii flyuidov (na primere bazhenovskoy svity Zapadnoy Sibiri) [Material composition in mechanism of formation of «intermediate header» in Domanic in fluid vertical migration zones]. 5-e Kudryavtsevskie Chteniya: Vserossiyskaya konferentsiya po glubinnomu genezisu nefti i gaza [ $5^{\text {th }}$ Kudryavtsev readings: All-Russian conference on oil and gas deep genesis]. Moscow, 2016. Moscow, TsGE Publ., 17-19 0ctober 2016. $5 \mathrm{p}$.

Received: 6 October 2018.

\section{Information about the authors}

Natalya M. Nedolivko, Cand. Sc., associate professor, National Research Tomsk Polytechnic University.

Tatyana G. Perevertaylo, Cand. Sc., associate professor, National Research Tomsk Polytechnic University. 